\title{
Knowledge, beliefs and attitudes of community health workers about hypertension in the Cape Peninsula, South Africa
}

\author{
MJ Sengwana, B Cur, School of Public Health, University of the Western Cape. \\ T Puoane*, Dr PH, School of Public Health, University of the Western Cape. \\ *This work was completed while employed at the Chronic Diseases of Lifestyle Unit of the Medical Research Council, \\ Parowvallei.
}

\section{Abstract}

This article explores the perceptions and attitudes of community health workers (CHWs) about hypertension. The level of knowledge of hypertension, as well as their personal attitude towards this is crucial in the style and quality of their interventions. CHWs, whose role in health promotion is being increasingly recognised, can help contain or reduce the prevalence of hypertension by influencing the community to adopt healthy lifestyles. Forty-three $\mathrm{CHWs}$ employed by Zanempilo in two study areas, Sites B and C in Khayelitsha in the Cape Peninsula, South Africa, were included in the study. Firstly, focus group discussions were conducted with 17 purposively selected $\mathrm{CHWs}$ to explore attitudes, beliefs and perceptions of hypertension. Secondly, interviews were conducted to assess their basic knowledge about causes, prevention and control of hypertension. The focus group discussions revealed that $\mathrm{CHWs}$ were uncertain about the causes of hypertension. They also found it difficult to grasp the fact that people without risk factors, such as overweight or a family history of hypertension, could be hypertensive. Many CHWs believe in traditional medicines and home-brewed beer as the best treatment for hypertension. They believe that people who take medical treatment become sicker and that their health deteriorates rapidly. Risk factors of hypertension mentioned during the structured interviews include inheritance, lack of physical activity, consuming lots of salty and fatty food. Conclusions drawn from the findings of the CHWs' responses highlighted their insufficient knowledge about hypertension as a chronic disease of lifestyle. Meanwhile they are expected to play a role in stimulating community residents' interest in the broad principle of preventive health maintenance and follow-up. Data obtained from this research can be used for the planning of health-promotion programmes. These should include preventing hypertension and improving primary management of individual sufferers. Because of their working relations and close link with $\mathrm{CHWs}$, community nurses in primary health-care facilities need to recognise these beliefs and attitudes since these may differ from their own.

\section{Abstrak}

Hierdie artikel ondersoek die insig en houdings van gemeenskapgesondheidswerkers ten opsigte van hipertensie. Hulle standaard van kennis van hipertensie, asook hulle persoonlike houding daarteenoor is deurslaggewend vir die styl en kwaliteit van hulle intervensies. Gemeenskapgesondheidswerkers se rol in die bevordering van gesondheid word al hoe meer erken, en kan help om die voorkoms van hipertensie onder beheer te hou of te verminder deur die gemeenskap te beïnvloed om 'n gesonde lewenstyl te volg. Drie en veertig gemeenskapgesondheidswerkers wat by Zanempilo in twee studiegebiede, Sektor B en C in Khayelitsha in die Kaapse Skiereiland, Suid-Afrika werksaam is, is by die studie betrek. Eerstens is fokusgroeponderhoude met 17 gemeenskapgesondheidsweŗkers wat doelbewus geselekteer is gevoer om hulle houdings, menings en insig omtrent hipertensie te ondersoek. Vervolgens is onderhoude gevoer om hulle basiese kennis omtrent die oorsake, voorkoming en hantering van hipertensie te bepaal. Die fokusgroeponderhoude het getoon dat gemeenskapgesondheidswerkers onseker is omtrent die oorsake van hipertensie. Hulle het gesukkel om te begryp dat mense sonder risikofaktore soos oorgewig, of 'n familiegeskiedenis van hipertensie ook hipertensief kan wees. Baie van hierdie werkers glo in tradisionele medisyne en tuisgemaakte bier as die beste behandeling vir hipertensie. Hulle glo dat mense wat op mediese behandeling is, sieker word en dat hulle gesondheid ook vinniger agteruitgaan. Risiko faktore vir hipertensie wat gedurende die gestruktureerde onderhoude genoem is, sluit oorerflikheid, 'n gebrek aan oefening, en 'n verhoogde sout- en vetinname in. Die gevolgtrekkings van die bevindings van gemeenskapgesondheidswerkers se antwoorde dui op hulle gebrekkige kennis van hipertensie as 'n chroniese lewenstylverwante siekte. Intussen word daar van hulle verwag om 'n rol te speel om die gemeenskap se belangstelling te prikkel aangaande die breë beginsel in die handhawing en voortsetting van voorkomende gesondheid. Data wat uit hierdie navorsing verkry is, kan gebruik word vir die 
beplanning van programme ter bevordering van gesondheid. Dit behoort die voorkoming van hipertensie in te sluit asook om die primêre hantering van indiwiduele lyers te verbeter. As gevolg van hulle werksverband en noue kontak met die gemeenskapgesondheidswerkers, behoort Gemeenskapsverpleegsters in die primêre gesondheidsorgdienste hierdie menings en houdings in ag te neem aangesien dit van hulle s'n kan verskil.

\section{Introduction}

Hypertension is an important public health problem, especially among the black urban South African population. Previous studies have reported age-adjusted prevalence of hypertension of $15-34 \%$ in all South African ethnic groups, but less prevalence in blacks residing in deep rural areas (Steyn, 1991). A national survey of 1998 (Steyn, Gaziano, Bradshaw, Laubscher \& Fourie, 2001:1722), using a cut-off point of $140 / 90 \mathrm{mmHg}$, reported an overall ageadjusted prevalence of $21 \%$ for hypertension. The prevalence was $23 \%$ and $25 \%$ in African men and women respectively.

Studies show that hypertension is positively associated with increased risk of coronary heart disease, stroke, congestive heart failure, end-stage renal disease and peripheral vascular disease (Rozanski, Blumenthal \& Kaplan, 1999:2192; Lunt, Edwards, Steyn, Lombard \& Fehrsen, 1998:544). Because of the high costs of curative and rehabilitative care toward hypertension, a population based approach preventive measure would be more cost effective, and community management would appear feasible in those already affected.

The contributions of socio-cultural, psychological, behavioural and health-care system factors are fundamental in achieving the magnitude of decrement in morbidity and mortality that can be attained through well-directed prevention strategies (Hill \& Becker, 1995:S123).

Most patients with hypertension are treated in primary care settings. Several studies have reported poor control of hypertension in patients attending health care facilities (Lunt et al., 1998:544; Steyn et al.. 2001:1717). Possible reasons for poor control include poor attendance at clinics and lack of compliance with treatment and lifestyle modification, which is probably due to beliefs held by patients about health and illness. Community-based nurses and health workers who supplement physician office-based practice are known to be effective in promoting cardiovascular health (Hill et al. 1995: S123). The CHW's positive role as key agents in improving health has been widely documented (World Health Organisation, 1989). Because of their understanding of the social environment, they are able to work closely with families to enhance active patient participation.

It was therefore necessary to explore the CHWs beliefs and attitudes about hypertension because non-governmental organizations are increasingly using them for their outreach programs (Felix-Aaron, Bone, Levine, \& Rubin, 2002:88). CHWs are persons trained to assist professional health personnel in communicating with residents in the community concerning needs and availability of health services. By influencing the community, including those at risk to adopt healthy lifestyle, the Community Health Workers (CHWs) can help reduce the prevalence of hypertension. Aside from these preventive measures and health education, they can assist in the management of the disease since the workload in primary health care facilities are often cited as a reason for the poor control of the disease.

CHWs included in this study were employed by Zanempilo (formerly known as SACLA), a non-governmental organization, to render health care services in under-resourced areas in and around Khayelitsha, Western Cape Province. They were residents of Khayelitsha and shared the same socio-cultural and demographic profiles as ordinary members of this community. In 2000, Zanempilo, at the request of the community agreed to add a component of health promotion in the activities of $\mathrm{CHWs}$. While $\mathrm{CHWs}$ play a role in health promotion in general, there have so far been no programs for primary prevention of cardiovascular diseases targeting CHWs in particular. Hence Zanempilo initiated chronic diseases of lifestyle programme with the aim to develop an intervention programme for primary prevention of cardiovascular diseases. The main aim of the study was to describe the knowledge, beliefs and attitudes of CHWs employed by Zanempilo about hypertension as this may have had an influence in their health promotion strategies at community level.

Khayelitsha is a large predominantly informal settlement located some $30 \mathrm{~km}$ from the centre of Cape Town Metropole Council. The size and population of the settlement is disputed, with estimates ranging from 350000 to 900000 . It is estimated that $43 \%$ of adults are unemployed. The majority of employed people fall into types of occupations that are typically unskilled and low-paid (The Social Economy of Khayelitsha, 2002:4). Public health problems such as HIV/ AIDS, under-nourishment, tuberculosis and inadequate health facilities in the area are matters of concern.

\section{Methodology}

Study design: An exploratory, qualitative and quantitative study aimed to describe the beliefs, attitudes and perceptions of CHWs, and to assess their basic knowledge of hypertension as a chronic disease of lifestyle.

Sampling procedure and data capture: All $43 \mathrm{CHWs}$ who were employed by Zanempilo in two study areas, Site B, and $C$ in Khayelitsha were included in the study. The study was structured in two data collection phases. In the first phase, two focus group discussions (FGDs) to explore the attitudes, beliefs and perception of hypertension based on socio-cultural backgrounds of CHWs were conducted with a purposive sample of $17 \mathrm{CHWs}$ (8 and 9) in each group. Two researchers conducted the discussions and used the CHW's indigenous language to exclude misunderstandings. A question 'We would like to find out what you, including the patients in the community know and believe about high blood pressure, that is, what is high blood 
pressure, what causes it, and how it is treated' was discussed in the two groups. A tape recorder was used and field notes were taken. Information obtained from group discussions was used to guide development of a questionnaire to validate the information collected through focus group discussions. The questionnaire was developed in English, then translated into isiXhosa and back translated on to English. In the second phase, CHWs were interviewed to assess basic knowledge about risk factors and control of hypertension.

Data analysis: Tape-recorded qualitative data from focus group discussions was transcribed ad verbatim by two researchers independently and then translated to English. Codes were developed after review of responses and two researchers independently grouped them according to the themes that emerged. Quantitative data from interviews was analysed using the EpiInfo 2000 computer program. Frequencies and percentages were calculated.

\section{Ethical Considerations}

The study assured complete confidentiality, as the data set and analysis were not linked to the name of the participants. The protocol to conduct this research was presented to and approved by the ethical committees of the Medical Research Council in Parowvallei and the University of the Western Cape in Bellville. The purpose of the study was explained to the participants and informed consent was obtained. The findings were presented to the Western Cape Department of Health, Zanempilo managers and the participants, and other stakeholders.

\section{Results}

\section{Focus group discussions (FGDS)}

Themes that arose from FGDs are discussed below.

\section{General perceptions about causes, prevention and control of hypertension}

Hypertension was defined according to their beliefs, which does not correspond to the medical definition.

'High blood pressure commonly known as hi-hi is when a person has too much blood in the body and the heart cannot manage to pump it well'.

CHWs had some understanding of the link between risk factors (perceived causes) such as high salt intake in diet; lack of exercises; stressful life and hypertension. They also related blood pressure to eating fatty foods.

'Hypertension is caused by eating too much salt and fatty food'. 'It is also caused by stress'.

CHWs indicated that most people were aware that if they do not take treatment as prescribed they may get stroke, but because they have many other problems, taking treatment is not a priority.

\section{Difficulty in understanding the risk factors for hypertension}

CHWs mentioned that most people from the community including themselves were uncertain about causes of hy- pertension.

'We understand that Hypertension is a disease common in overweight people, but we also see thin people who adhere to healthy living (these people were considered not at risk) with no family history of hypertension, but told that they suffer from hypertension. Most of the people think that hypertension is therefore caused by witchcraft'.

\section{Hypertension is a society norm}

The CHWs thought that it was normal for adults to be taking treatment for hypertension.

'Almost every adult in the community is on treatment for hi-hi (hypertension). People are surprised to meet someone above 50 years who is not on treatment for hypertension. It is just like overweight, almost all women in the community are overweight'.

\section{Hypertension control versus poverty}

The CHWs mentioned that community members are not concerned about hypertension as a chronic disease, but are more worried about poverty.

'People are not concerned about hi-hi, because of poverty. They worry about what they are going to eat ... people are depressed about their poverty situation and some are very stressed ... people are not working and this forces them to eat whatever is available. You may find that one person in the house has diabetes or hypertension but cannot control her diet because the little food available has to be shared with the whole family'.

'People usually ask-how can I take medicine in an empty stomach?'

\section{Compliance to treatment}

Much as they understood the incurable nature of hypertension - to them this was another medical notion. They believed that traditional remedies like natural herbs and home brewed beer could control the disease. Medical treatment was considered "toxic" and had short-term effects. Some people skip medication or take less than what is prescribed to avoid unwanted effects.

'You cannot take tablets for the rest of your life ... it's poison ... people get tired'.

'The tablets make people more sicker. They become very sleepy. One man told me that his wife had accused him of having an affair with another women because he was always sleepy. Even during the night he could not wake up at all'.

'One woman told me that the tablets make herpass a lot of urine. To avoid going to the toilet during the night she is taking one tablet instead of two that were prescribed'. Patients seem not to take prescribed treatment as expected. They only take treatment few days before they visit the clinic for check-up. They do not often tell the doctors that they are taking other home remedies.

'One patient told me that he never took his prescribed 
tablets but took half a cup of home brewed beer every day. When he went for routine follow-up the doctor who checked his blood pressure said well done, your blood pressure is $O k$, continue with the same treatment you are taking. The man went to tell other patient that the home brewed beer works'.

\section{Cultural beliefs}

CHWs indicated that they found it difficult to discourage some of the beliefs and attitudes held by the community about the treatment of hypertension.

'It is difficult for us to advice people not to take traditional and home remedies because it is part of our culture to take some herbal medicine routinely. We believe in protecting ourselves from evil spirits. I remember when we were growing up we used to drink herbal medicine everyday and we never got sick, maybe if hypertension could be treated with medicine instead of tablets patients may take the medicine as required'.

\section{Problems with the staff and the health system}

CHWs indicated that some patients rather reduce the treatment so that it last them longer in order to delay going back to the clinics for check-up.

'Patients tell us that visiting the clinics means getting up at 4 am in order to be at the clinic door by 5am. Otherwise they would sit at the clinic for the whole day. They also complain about lack of respect from the nurses who talk to them anyhow'.

\section{Interviews}

\section{Demographic Profile and History of Illness}

A statistical profile of CHWs showed that 38 were females and 5 males, ranging in age from 29 to 59 years (mean 43 years). Education levels ranged from 4 to 12 years of schooling with $35 \%$ having attained grades 11 or 12 . Thirty-six (80\%) had worked as CHWs for more than 5 years. Twentytwo $(51 \%)$ had basic training in hypertension, and $21(49 \%)$ had a family member who suffered from hypertension. Ten of CHWs who participated in this study suffered from hypertension.

\section{Knowledge About Hypertension \\ Perceived risk factors for hypertension}

A large percentage of CHWs mentioned that consuming lots of fat was a risk factor for hypertension. Only few of them mentioned overweight (Table 1).

\section{Organs affected by hypertension}

As Table 2 depicts, $88 \%$ of participants mentioned the heart as an organ most affected in hypertensive patients followed by blood vessels, liver and kidney.
Table 1: Perceived causes (risk factors) of hypertension $(n=43)$

\begin{tabular}{|l|l|l|l|l|}
\hline & \multicolumn{2}{|c|}{ Mentioned } & \multicolumn{2}{l|}{ Not Mentioned } \\
& $\mathrm{n}$ & $\%$ & \multicolumn{2}{l|}{$\mathrm{n}$} \\
\hline Lots of fat & 37 & 86 & 6 & 14 \\
\hline Inheritance & 16 & 37 & 27 & 62 \\
\hline Lack of exercise & 13 & 30 & 30 & 69 \\
\hline Lots of starch & 13 & 30 & 30 & 69 \\
\hline Lots of salt & 12 & 28 & 31 & 72 \\
\hline Overweight & 5 & 11 & 39 & 87 \\
\hline
\end{tabular}

\section{Table 2: Organs perceived as affected in patients with hypertension ( $n=43)$}

\begin{tabular}{|l|c|c|c|c|c|c|}
\hline & \multicolumn{2}{|c|}{$\begin{array}{l}\text { Mentioned } \\
\text { n }\end{array}$} & \multicolumn{2}{c|}{$\begin{array}{l}\text { Not Mentioned } \\
\text { n }\end{array}$} & \multicolumn{2}{c|}{$\begin{array}{l}\text { Don't know } \\
\text { n }\end{array}$} \\
\hline Heart & 38 & 88 & 3 & 7 & 2 & 5 \\
\hline Blood vessels & 4 & 9 & 37 & 86 & 2 & 5 \\
\hline Liver & 3 & 7 & 38 & 88 & 2 & 5 \\
\hline Kidney & 2 & 5 & 39 & 91 & 2 & 5 \\
\hline Lungs & 1 & 2 & 40 & 93 & 2 & 5 \\
\hline
\end{tabular}

Table 3: Advice (lifestyle modification) given to hypertension sufferers

\begin{tabular}{|l|l|l|l|l|}
\hline & \multicolumn{2}{|c|}{ Mentioned } & \multicolumn{2}{c|}{ Not Mentioned } \\
& n & \% & n & \multicolumn{2}{c|}{$\%$} \\
\hline Eat less fat & 34 & 79 & 9 & 21 \\
\hline Do not use salt & 23 & 53 & 20 & 47 \\
\hline Do exercises & 4 & 9 & 39 & 91 \\
\hline Do not smoke & 2 & 5 & 41 & 95 \\
\hline Have time to relax & 1 & 2 & 42 & 98 \\
\hline
\end{tabular}

\section{Advice given to hypertensive patients}

Seventy nine percent of CHWs indicated that they tell patient to eat less fatty foods, reduce salt intake $(56 \%)$ increase physical activity (9\%) stop smoking (4\%). Table 3.

\section{Measures taken to control hypertension}

Most CHWs (93\%) mentioned that the important control measure for hypertension is taking treatment regularly. The least mentioned were weight control and reduction of alcohol intake (Table 4).

\section{Discussion}

This study has used a combination of qualitative and quan- 


\section{Table 4: Health care measures taken in the presence of hypertension}

\begin{tabular}{|l|l|l|l|l|}
\hline & \multicolumn{2}{|l|}{ Mentioned } & \multicolumn{2}{l|}{ Not Mentioned } \\
& n & \% & \multicolumn{2}{l|}{ \% } \\
\hline Exercises & 18 & 41 & 25 & 58 \\
\hline Less fat & 16 & 37 & 27 & 63 \\
\hline Mixtures e.g. aloe & 14 & 33 & 29 & 67 \\
\hline Less salt & 9 & 21 & 34 & 79 \\
\hline Traditional beer & 9 & 21 & 34 & 79 \\
\hline Tradition medicine & 5 & 12 & 38 & 88 \\
\hline No alcohol & 3 & 7 & 40 & 93 \\
\hline Control weight & 2 & 5 & 41 & 95 \\
\hline Medical treatment & 40 & 93 & 3 & 7 \\
\hline
\end{tabular}

titative methods to gain a better understanding of the knowledge, beliefs and attitudes of CHWs about hypertension. Understanding the beliefs of this category of health workers is necessary as they are a link between the community they serve and the health sector. Lack of appreciation of the beliefs of this category of health workers may contribute to persistently poor rates of hypertension control.

CHWs seemed to have insufficient knowledge and health information on the prevention and management of hypertension. Accompanying lack of knowledge was the fact that they found it difficult to understand who is at risk of getting these diseases because their experience suggest that anybody irrespective of weight or eating habits has the chance of getting the disease.

Although overweight was mentioned as a risk factor for hypertension, it was least mentioned as a health measure to control hypertension. This may be due to positive perceptions that this population is overweight. An earlier study (Puoane, Rosling, De Goede \& Van der Meij, 2001:225) undertaken among the participants of this study reported that overweight was associated with dignity, respect and dignity, respect, confidence, and good feeling good about one self. Studies have indicated that exercises and weight loss can lower blood pressure in hypertensive patients as well as in normotensive patients (Georgiades, Sherwood, Gullette, Babyak, Hinderliter, Waugh, Tweedy, Craighead, Bloomer \& Blumenthal 2000:174). In a population where overweight is valued it is very difficult to encourage people to lose weight but, if we encourage them to adopt healthy lifestyles by making healthy choices about the food they eat and increase physical activity we may help to reduce the prevalence of chronic diseases in this population.

A recurring theme is that of combining medical treatment with traditional remedies including herbal medicine. This is supported by the findings of Daniels, Biesma, Otten, Levitt, Steyn, Martell and Dick (2000:1208), who found that patients discontinued prescribed medication in favour of traditional remedies. Wilson, Freeman, Kadza, Andrews, Berry, Vaeth, and Victor (2002:26) also found that middle-low in- come urban African-American believed that high blood pressure was linked to eating pork and was considered treatable with other herbs. This behaviour, which seem to be common in other cultures may be due to lack of understanding of the benefits of taking the treatment even in the absences of pain. Does this population know the benefits of taking the treatment even if there is no pain? This is especially of concern because most of black South African population do not usually go for medical or physical checkups. It is when individuals experience pain that medical help is usually sought (Mbombo 1996: 109). Another possible explanation is a difficulty in understanding the concept of a "chronic condition". People usually visit a doctor looking for a cure of their disease. Some fail to understand why they should continue with the treatment for life. Therefore, they conclude that the western medicine is not very effective, and start looking around for the cure for the condition. Because hypertension is not associated with pain, patients often think that they are well, and only take prescribed treatment when they feel sick or have a headache.

The manner in which health personnel communicate messages to patients may also influence adherence to treatment. Patients may just listen to orders given to them without negotiation but may inwardly say "you may tell me what to do, I will make a decision about what to do because this is my life and my body'. Weiss and Hutchinson (2000:521), examined factors affecting adherence to healthcare directions in patients with diabetes and hypertension, and reported that patients felt the pressure to adhere to treatment but did not feel like having a partnership relationship with their health providers. Patients therefore need to be informed about their rights to health care and healthcare providers should be encouraged to establish a therapeutic partnership with patients so as to improve control of hypertension.

Financial hardship is a barrier, which should not be ignored, as it is a contributory factor to non-compliance. If people are hungry nothing matters except food. People either take the treatment very late when they have had something to eat or forget about the treatment at all while trying to deal with other problems of poverty. Maybe health personnel need to think about how to assist poor patients with chronic conditions. People who reside in informal houses may not have access to toilets facilities; they may therefore reduce or omit their medication in order to avoid going out to look for a toilet during the night. The situation constitutes also a barrier to compliance to treatment.

The study implies that because they are lay people, CHWs need to be orientated and trained in the prevention and management of chronic diseases including hypertension before they execute their roles in communities. To address the growing problem of non-communicable diseases in South Africa, the health authorities need to initiate programmes for the cost-effective management of chronic diseases through the use community health workers. Although information about CHWs and their role in the prevention of cardiovascular diseases has not been widely documented, some studies have shown that if integrated into the pri- 
mary health system, CHWs bridge the gap between poor communities and health care facilities. Because of their working relations and close link with community health workers, community nurses in primary health care facilities need to recognize these beliefs and attitudes as they may differ from theirs hence establish the pros and cons of health-care delivery in communities. However, the limitations were that these findings could not be generalised as the study was conducted in one setting and therefore needs to be replicated in other settings in order to get a broader view on this subject.

\section{Recommendations for the improvement of health promotion strategies by CHWs}

- A training program for the primary prevention of cardiovascular diseases should be initiated. Education and information should include: Basic anatomy and physiology; the role of nutrition, physical inactivity, body weight, smoking and alcohol in causation of hypertension. Patients suffering from hypertension should be given culturally accurate dietary and lifestyle information about their diseases by CHWs who are an entry point to health system for residents.

- Future research should look at the contents of homebrewed beer to find out what it is that lowers the blood pressure or makes people who take it feel better.

- Community nurses need to consider the inclusion of a community health workers' programme in primary health care to enable them to recognize their role in health promotion and prevention of diseases.

- Ongoing evaluation of $\mathrm{CHWs}$ is crucial as more health-care providers and non-governmental organizations increase their use for outreach programmes.

\section{Acknowledgements}

This was a collaborative project between the Medical Research Council, Parowvallei, School of Public Health, UWC, Zanempilo Trust, Provincial Administration of the Western Cape, University of Cape Town and Sport Science Institute, and Peninsula Technikon. The authors would like to acknowledge: Zanempilo Health Project for inviting us to collaborate with them, the community health workers for participating in the study, and their managers for arranging fieldwork. We would also like to acknowledge Debra Jackson and Jean Fourie for their support and encouragement when writing this paper.

\section{References}

DANIELS A; BIESMA R; OTTENJ; LEVITT NS; STEYN K; MARTELL R \& DICK J 2000: Ambivalence of primary health care professionals to the South African guidelines for hypertension and diabetes. South African Medical Journal, 90:1206-1211.
FELIX-AARON KL; BONE LR; LEVINE DM \& RUBIN HR 2002: Using participant information to develop a tool for the evaluation of community health worker outreach services. Ethnicity \& Disease. 12(1): 87-96.

GEORGIADES A; SHERWOOD A; GULLETTE CD; BABYAK MA; HINDERLITERA; WAUGH R; TWEEDY D; CRAIGHEAD L; BLOOMER R \& BLUMENTHAL JA 2000: Effects of exercise and weight loss on mental stressinduced cardiovascular responses in individuals with high blood pressure. Hypertension. 36 (2): 171-176. [Medline].

HILL MN \& BECKER DM 1995: Roles of Nurses and Health Workers in Cardiovascular Health Promotion. The American Journal of the Medical Sciences, 310 (suppl 1): S123-S126.

LUNT DWR; EDWARDS PR; STEYN K; LOMBARD CJ \& FEHRSEN GS 1998: Hypertension care at a Cape Town community health centre. South African Medical Journal. 88(5): $544-548$.

MBOMBO O 1996: Practicing Medicine Across Cultures: Conceptions of Health, Communication and Consulting Practice. In Steyn ME \& Motshabi KB. (Eds). Cultural Synergy in South Africa. Weaving Strands of Africa and Europe. Randburg: Knowledge and Resources, pp 109.

PUOANET; ROSLINGL; DEGOEDEJ \& VANDER MEIJ B 2001: Weight-Related Beliefs and Attitudes of Obese Urban Women. Cardiovascular Journal of South Africa. 12 (4): 225.

ROZANSKI A; BLUMENTHAL JA \& KAPLAN J 1999: Impact of psychological factors on the pathogenesis of cardiovascular disease and implications for therapy. $\underline{\text { Circu- }}$ lation. 99(16): 2192-2217.

STEYN K 1991: The epidemiology of hypertension in South Africa and the implications for clinical practice. Proceedings of the Advanced Course in Medicine. The College of Medicine in South Africa, November.

STEYN K; GAZIANOTA; BRADSHAW D; LAUBSCHER J \& FOURIE JM 2001: Hypertension in South African adults: Results from the Demographic Health Survey, 1998. Journal of Hypertension. 19(9): 1717-1725.

THESOCIAL ECONOMY OF KHAYELITSHA 2002: Demographic Information. [Available:

http://www.local.gov.za/DCD/ledsummary/khayelitsha/ socialeconomy.html].

WEISS J \& HUTCHINSON SA 2000: Warnings about vulnerability in clients with Diabetes and Hypertension. Qualitative Health Research. 10 (4): 521-537.

WILSON RP; FREEMANA; KAZDAMJ; ANDREWSTC; BERRY L; VAETH PAC \& VICTOR RG 2002: Lay beliefs about High Blood Pressure in a Low-to Middle-Income 
Urban African-American Community: An Opportunity for Improving Hypertension Control. The American Journal of Medicine, 112(1): 6-30.

WORLD HEALTH ORGANIZATION 1989: Strengthening the performance of community health workers in primary health care. Report of a WHO Study Group. (WHO Technical Report Series, No 780) Geneva, World Health Organisation. 